\title{
Shallow structures at the outer Calabrian accretionary wedge (NW Ionian Sea): new insights from recently migrated reflection data
}

\author{
Vera Valenti \\ Dipartimento di Geologia e Geodesia, Università di Palermo, Via Archirafi 20, 90123 Palermo, Italy
}

\begin{abstract}
Post-stack time migration of a set of seismic reflection profiles reveals details of the stratigraphic-structural setting of the outermost Calabrian accretionary wedge, in the NW sector of the Ionian Sea, with particular emphasis on the Messinian stratigraphy and the deformation style of the thin frontal portion of this wedge. A structural style and seismic facies analysis, calibrated by refraction data, images a general bipartition of the Messinian evaporite deposits: the 'lower subunit', consisting mainly of salt, appears to have undergone ductile-flow deformation, and the 'upper subunit', consisting mainly of gypsum and marls, appears to be
\end{abstract}

characterized by brittle deformation. Lateral variations in evaporite composition and/or thickness reflect a change in the deformation style of the accretionary wedge, with the development of double-verging imbricated thrust sheets of the whole Messinian sequence. Gravitational-slide tectonics of the unstable accretionary wedge, too steep to support a skinny evaporite-based top layer, characterize the outermost wedge, indicating here a near-surface 'olistostrome' from the Late Messinian.

Terra Nova, 22, 453-462, 2010

\section{Introduction}

Tectonic sedimentary accretion is a well-established geological process at active continental margins, where offscraping, progressive deformation and piling up of deep-sea sediments combine to form a sequence of several imbricate thrust sheets of the accretionary wedge.

As the wedge construction processes are strongly influenced by both the dip of the basal décollément level and its mechanical characteristics [as described by the 'Coulomb wedge' theory (Davis et al., 1983)], a detailed study of the deformation front could provide a good source of information for understanding the wedge's evolution and mechanics.

The External Calabrian Arc (hereinafter ECA) was formed by the convergence of the African and European regions and the subduction of the Ionian plate beneath the Calabrian plate, as is clearly defined by seismicity (Chiarabba et al., 2008), the temporal and spatial pattern of volcanic activity (De Astis et al., 2003) and seismic tomography (Wortel and Spakman, 2000): offscraped sediments

Correspondence: Dr Vera Valenti, Department of Geology and Geodesy, University of Palermo, Via Archirafi, 20/22, 90123 Palermo, Italy. Tel.: +393405053830; e-mail:valv@unipa.it from the subducting Ionian plate have piled up along thrust faults opposite the European region. However, the ECA is a unique accretionary wedge showing, unusually, both a low décollément dip and narrow taper (Lenci and Doglioni, 2007) and the highest outward growth rate of its deformation front (Torelli et al., 2007), perhaps reflecting the occurrence of Messinian salt within the wedge (e.g. Polonia et al., 2008).

Although regional geophysical studies conducted over the past 20 years suggest constraints on the internal structure of the ECA (e.g. Catalano and Sulli, 2006), few, if any, of these studies have discussed in detail its thin frontal portion, i.e. the transition of the ECA to the Ionian abyssal plain. I believe that this is the reason why major questions remain unanswered: (1) are the Messinian evaporites composed of salt that makes them behave as a weak décollément level? and (2) how do the Messinian evaporites influence the tectonic style and geometry of the wedge?

Until now, the seismic character of the Messinian evaporites, in terms of reflectivity patterns and deformational structures, has not been convincingly related to their stratigraphic layering and rheology. That is because the rough sea-bed topography (otherwise known as the 'cobblestone topography', Hersey, 1965) at the ECA's southernmost front and the occur- rence, at depth, of diffraction hyperbolae coming from the Messinian evaporitic sequence have strongly hampered the study of the ECA's internal structure.

The aforementioned questions are addressed here through analysis of a recently migrated set of seismic reflection profiles from the NW Ionian Sea around the front of the wedge, to the east and south-east of the Malta Escarpment (Fig. 1). A new detailed seismostratigraphic analysis allows a better definition of the seismic stratigraphy of the Messinian evaporite deposits. The style of deformation at the front of the wedge in different transects is analysed, and the role played by Messinian evaporites in controlling the tectonic style of the thin frontal portion of the wedge is discussed.

\section{General background}

The SE-verging ECA is an active arcshaped accretionary wedge (Sartori, 1982), developing above the NWplunging Ionian oceanic basement and its Mesozoic to Tertiary (Catalano et al., 2001) sedimentary cover.

In the outermost part of the ECA, the main regional décollément surface is located at the base of the Messinian evaporite deposits (Merlini et al., 2000; Chamot-Rooke et al., 2005; Finetti, 2005; Polonia et al., 2008). The occurrence of evaporites is often 


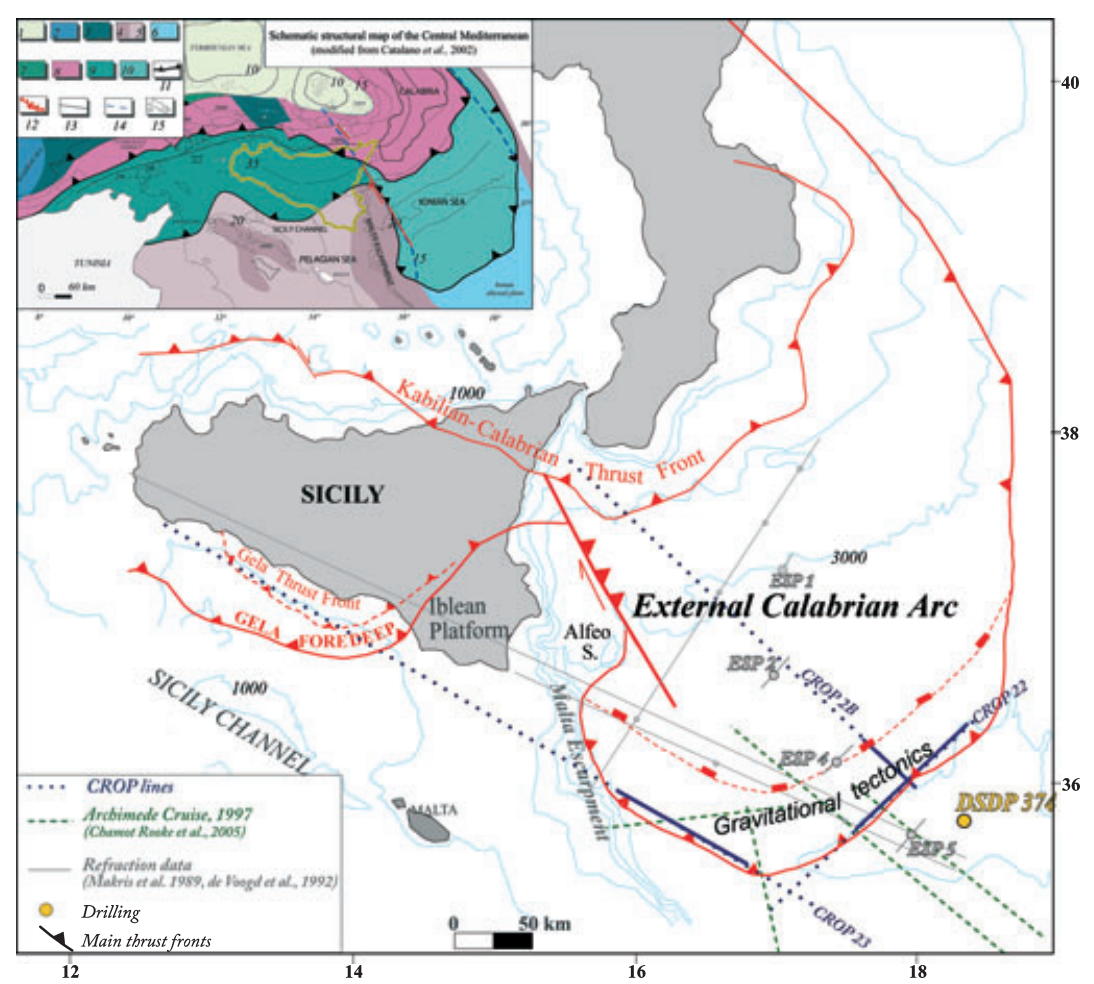

Fig. 1 Bathymetric map of the study area. The grid of the interpreted (CROP) multichannel seismic profiles (bold segments), together with the locations of seismic reflection lines, seismic refraction profiles and drilling that contribute to the seismic interpretations proposed in this paper, are shown. Main structural features based on present and previously published (Catalano et al., 2001; Chamot-Rooke et al., 2005) studies are displayed. Inset shows a schematic structural map of the study area and surrounding area. The numbers in the legend are: (1) Tyrrhenian deep basin; (2) Algerian basin; (3) thinned Sardinia and Kabilian continental crust; (4) African continental thinned crust; (5) African continental crust; (6) Ionian oceanic basin; (7) Sardinia units; (8) Kabilian-Calabrian units; (9) Sicilian-Maghrebian units; (10) Ionian accretionary wedge; (11) thrust fronts; (12) transtensional fault; (13) Moho isobaths in km; (14) hypothetical Ionian crustal boundary; and (15) bathymetry. For a detailed bathymetric map, see Polonia et al. (2008), fig. 1 therein.

expressed by a peculiar morphology known as 'cobblestone topography' because of the presence of km-size, convex-upward features well imaged by seismic surveys (e.g. Rossi and Sartori, 1981) of the ECA.

Both the SE-dipping topographic slope of the wedge $\left(\right.$ about $1^{\circ}$ ) and the wedge taper (about 2-3 $3^{\circ}$; Torelli et al., 2007; Polonia et al., 2008) are very low compared with other prisms worldwide (Clift and Vannucchi, 2004; Lenci and Doglioni, 2007). These values require low basal friction conditions or a weak décollément level (Davis et al., 1983; Dahlen et al., 1984), usually of salt. The occurrence of salt within the ECA has been locally highlighted by multi-offset reflection and refraction seismic surveys (Finetti, 1982, 2005; Makris et al., 1986; De Voogd et al., 1992; Cernobori et al., 1996; Stampfli et al., 2001; Chamot-Rooke et al., 2005; Polonia et al., 2008). Nevertheless, deformation structures observed on seismic profiles do not provide evidence of salt-involved tectonics, perhaps because of the lack of highquality data.

Near the outer front of the ECA, shortening of the post-Messinian deposits results from slumps or mass gravity flows (based on high-definition, multibeam data) that have been related, in turn, to a gravitational collapse at the top of the evaporites in the presently starved Calabrian subduction (Chamot-Rooke et al., 2005).

\section{Dataset}

To constrain better the main features of the thin frontal part of the ECA, I use recently migrated multichannel seismic profiles acquired in the 1990s within the framework of the Italian deep crust exploration project (CROP Project, Fig. 1). Application of migration techniques to the CROP dataset focused on imaging, in detail, the shallow subsurface in the 1.0 $2.0 \mathrm{~s} / \mathrm{TWT}$ range. The recording parameters of the profiles are listed in Table 1.

An earlier conventional processing sequence carried out by the Osservatorio Geofisico Sperimentale (OGS) of Trieste (Table 2) did not yield clear,

Table 1 Main recording parameters of CROP profiles.

\begin{tabular}{|c|c|}
\hline Shot by & OGS \\
\hline Vessel & OGS Explora \\
\hline Recording format/density & SEG D - $6250 \mathrm{BPI}$ \\
\hline Sampling rate & $4 \mathrm{~ms}$ \\
\hline Recording length & $17 \mathrm{~s} / \mathrm{TWT}$ \\
\hline $\begin{array}{l}\text { Recording length } \\
\text { (line CROP 2B) }\end{array}$ & $21 \mathrm{~s} / \mathrm{TWT}$ \\
\hline Low cut frequency & OUT \\
\hline High cut frequency & $\begin{array}{r}77 \mathrm{~Hz} \text { slope } \\
53 \mathrm{~dB} / \text { oct }\end{array}$ \\
\hline No. active groups & 180 \\
\hline Streamer & $4500 \mathrm{~m}$ \\
\hline Group interval & $25 \mathrm{~m}$ \\
\hline Basic group length & $25 \mathrm{~m}$ \\
\hline $\begin{array}{l}\text { No. hydrophones } \\
\text { for groups }\end{array}$ & 32 \\
\hline Offset (source/1st group) & $125 \mathrm{~m}$ \\
\hline Streamer depth & $12 \mathrm{~m}( \pm 1 \mathrm{~m})$ \\
\hline Nocht frequency & $62 \mathrm{~Hz}$ \\
\hline Streamer sensitivity & $10 \mathrm{~V} \mathrm{bar}^{-1}$ \\
\hline Nominal fold & $4500 \%$ \\
\hline $\begin{array}{l}\text { Nominal fold } \\
\text { (line CROP 2B) }\end{array}$ & $3600 \%$ \\
\hline Energy source & Air Gun \\
\hline Array type & TUNED-D080/103/06 \\
\hline Total array volume & 4906 Cu.in-80.40 L \\
\hline Operating pressure & 2000 Psi-140 bar \\
\hline Operating tolerance & $\pm 10 \%$ \\
\hline Power output & 103.4 bar m$^{-1}$ \\
\hline No. subarray & 4 \\
\hline $\begin{array}{l}\text { Guns no. subarray/ } \\
\text { subvolume }\end{array}$ & 8/1226.5 Cu.in \\
\hline Subarray length & $14 \mathrm{~m}$ \\
\hline Total guns number & 32 \\
\hline Source length & $56 \mathrm{~m}$ \\
\hline Source width & $45 \mathrm{~m}$ \\
\hline Operating depth & $8 \mathrm{~m}$ \\
\hline Notch frequency & $93.7 \mathrm{~Hz}$ \\
\hline Shot interval & $50 \mathrm{~m}$ \\
\hline $\begin{array}{l}\text { Shot interval } \\
\text { (line CROP 2B) }\end{array}$ & $62.5 \mathrm{~m}$ \\
\hline
\end{tabular}


Table 2 Main processing steps and parameters of CROP profiles original stacks.

\begin{tabular}{lll}
\hline Step & Process & Details \\
\hline 1 & CODE-4 CONVERSION & Time sampling to $8 \mathrm{~ms}$ \\
2 & RESAMPLING & Wind $0.017 \mathrm{~s} 2 / 24$ out $\mathrm{Hz} / \mathrm{dB}$ \\
3 & GEOMETRY UPDATE & \\
4 & PRE-FILTER. & Predictive minimum phase inv. filter 3 wind $32-$ \\
5 & ARRAY SIMULATION & 300 ms operator \\
6 & TRACE EQUALIZATION & F/K domain filter applied on CDP gathers NMO \\
7 & DECONVOLUTION & corrected by multiple velocity field and pass only \\
8 & PRELIMINARY VELOCITY ANALYSIS & negative events \\
9 & MULTIPLE ATTENUATION & Inside and outside mute applied to remove stretched \\
& & data and refracted signals \\
10 & VELOCITY ANALYSIS & Starting about $2 \mathrm{~s}$ from seabed $\pm 12 / \pm 40 \mathrm{~ms} / \mathrm{tr}$ \\
11 & NMO/STACK & REJECT \\
12 & ZERO PHASE CONVERSION & Radial Predictive Filter, 7 traces Wind $0.0-1.3 \mathrm{~s}$ dip \\
13 & F-K FILTER & \\
14 & MULTICHANNEL FILTER & \\
15 & TIME VARIANT FILTER & \\
16 & PLOTT & \\
\hline
\end{tabular}

high-quality, seismic stack sections. Multiple reflections and diffraction hyperbolas, created at the seafloor, within the accretionary wedge and at the basement, were very frequent (Fig. 2a).

I carried out post-stack Kirchhoff time migration (Berkhout, 1980) at the CERI (Memphis, TN, USA), using the software ProMAX by Landmark Graphics, Corp. (Houston, TX, USA). I focused on the velocity distribution with depth, by utilizing the results of the Expanding Spread Profile (ESP) data supplied by De Voogd et al. (1992). Improvement of the data quality and enhancement of the signal-tonoise ratio of the data are shown in Fig. 2, wherein both unmigrated and migrated stack sections are illustrated.

\section{Stratigraphy}

In the outer ECA, the Deep Sea Drilling Project (DSDP) site (No.

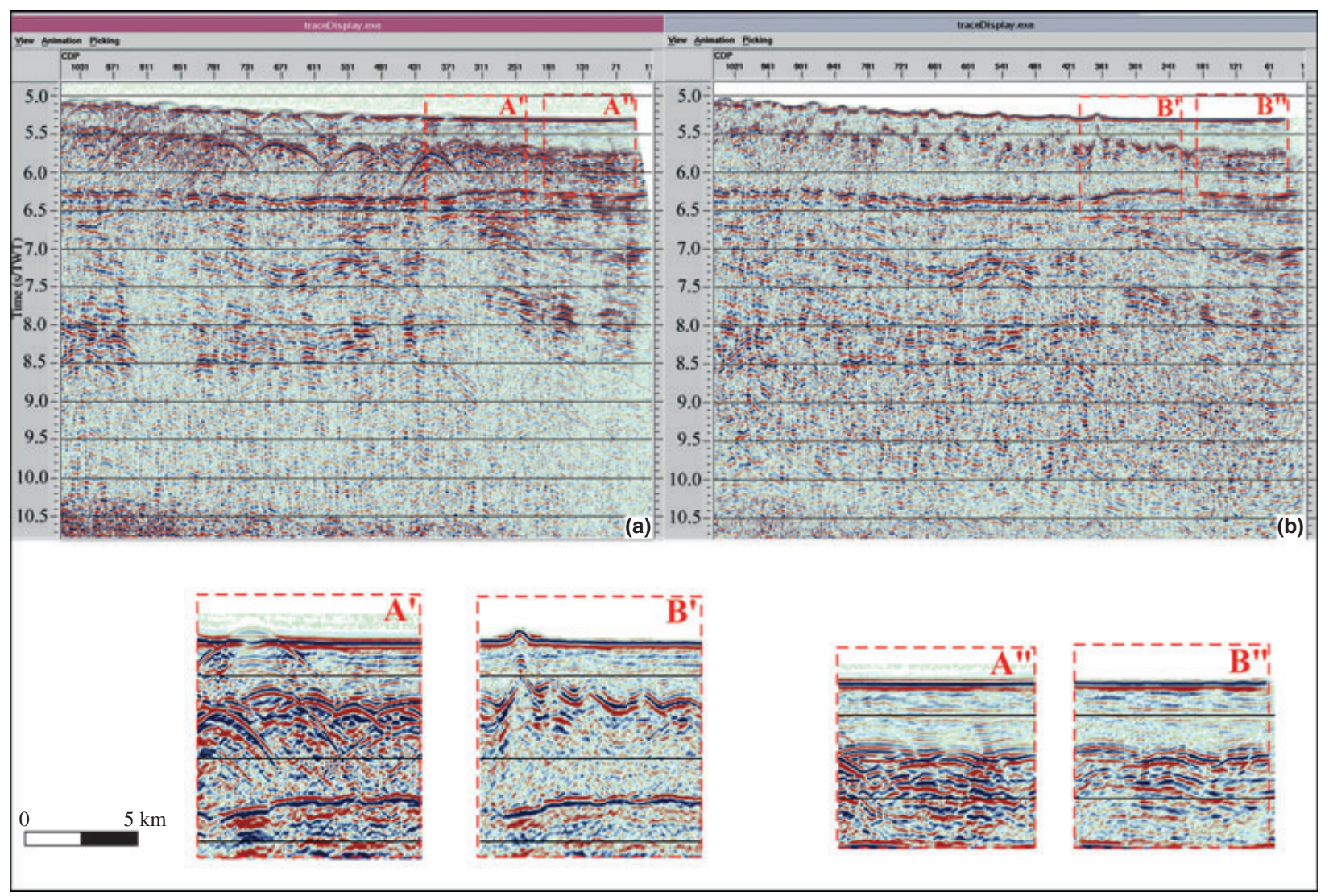

Fig. 2 Comparison between (a) an original unmigrated section and (b) the post-stack time migration section. Note a diffracted energy package well recognizable from 5.5 to $6.3 \mathrm{~s}$ /TWT in (a), coming from the Messinian evaporite deposits; the diffracted energy is well collapsed at its source point in (b). Close-ups are also shown. Also, the noise around $10.5 \mathrm{~s} / \mathrm{TWT}$ on the unmigrated section disappears on the migrated section. For the location, see Fig. 4. 
374; Fig. 1; Hsu et al., 1978) and seismic data (e.g. Finetti, 1982) show that up to $400 \mathrm{~m}$ of PlioQuaternary deposits overlie the Messinian evaporitic sequence. The thickness of the Messinian deposits varies from about $1300 \mathrm{~m}$ to about $2800 \mathrm{~m}$ (De Voogd et al., 1992). However, direct observation of the composition of the evaporitic sequence in the Ionian Sea, i.e. the DSDP drilling, is poor; it penetrates only about $80 \mathrm{~m}$ beneath the base of the Pliocene and some $40 \mathrm{~m}$ into gypsum-bearing and salt horizons (Hsu et al., 1978).

As a consequence, knowledge of the stratigraphy of the Messinian deposits is limited to inferences from seismic data.

Correlation of the OD-22 seismic reflection profile with DSDP results (including the P-velocity measurements; Hsu et al., 1978; see fig. 15 therein) suggests a bipartition of the Messinian sequence, which is made up of a transparent 'salt layer' at the bottom and well-layered 'upper evaporites' at the top, consisting of gypsum/dolomitic mudstone cycles.

A similar bipartition is suggested by previous workers, using seismic reflection and/or refraction data (Table 3).

A subdivision into 'upper' and 'lower' evaporites comes also from Sicilian onshore mine and borehole data (e.g. the Braemi well, Fig. 3); these divisions are otherwise known as First and Second Cycle Evaporites (Decima and Wezel, 1971; Butler et al., 1995; Roveri et al., 2006).

Inferences from seismic data (Catalano et al., 2001; see fig. 8 therein) suggest that the substratum of the Messinian evaporites consists of a 4-km-thick unit, seismically interpreted as pelagic deposits from the Mesozoic to Early Messinian.

\section{Seismic interpretation}

For the description of the seismic stratigraphy, I use a representative portion of the CROP 22 profile that exhibits (Fig. 4) from the top to the bottom:

1 A 0.2 - to $0.4-\mathrm{s} / \mathrm{TWT}$ thick sequence, with good lateral continuity, lowamplitude and high-frequency reflectors; it shows planar to sub-planar geometry (unit A). The P-velocity

Table 3 Subdivision of Messinian evaporites based on seismic facies analysis and/or its calibration with P-velocities, compiled from previous work (modified from Tay et al., 2002).

\begin{tabular}{lll}
\hline Montadert et al. (1978) & Upper evaporites (evaporites and marls & Alternance of low and high \\
& encountered in DSDP boreholes) & velocities, from 3.5 to $4.4 \mathrm{~km} \mathrm{~s}^{-1}$ \\
& Salt (halite-anhydrite) & $4.5 \mathrm{~km} \mathrm{~s}^{-1}$ \\
Camerlenghi (1991) & Upper evaporite (gypsum and marls) & $3.0-3.3 \mathrm{~km} \mathrm{~s}^{-1}$ \\
& Lower evaporite (salt) & $4.3-4.8 \mathrm{~km} \mathrm{~s}^{-1}$ \\
De Voogd et al. (1992) & Upper evaporite & $4.4-4.5 \mathrm{~km} \mathrm{~s}^{-1}$ \\
& Lower evaporite & $4.2 \mathrm{~km} \mathrm{~s}^{-1}$ \\
\hline
\end{tabular}

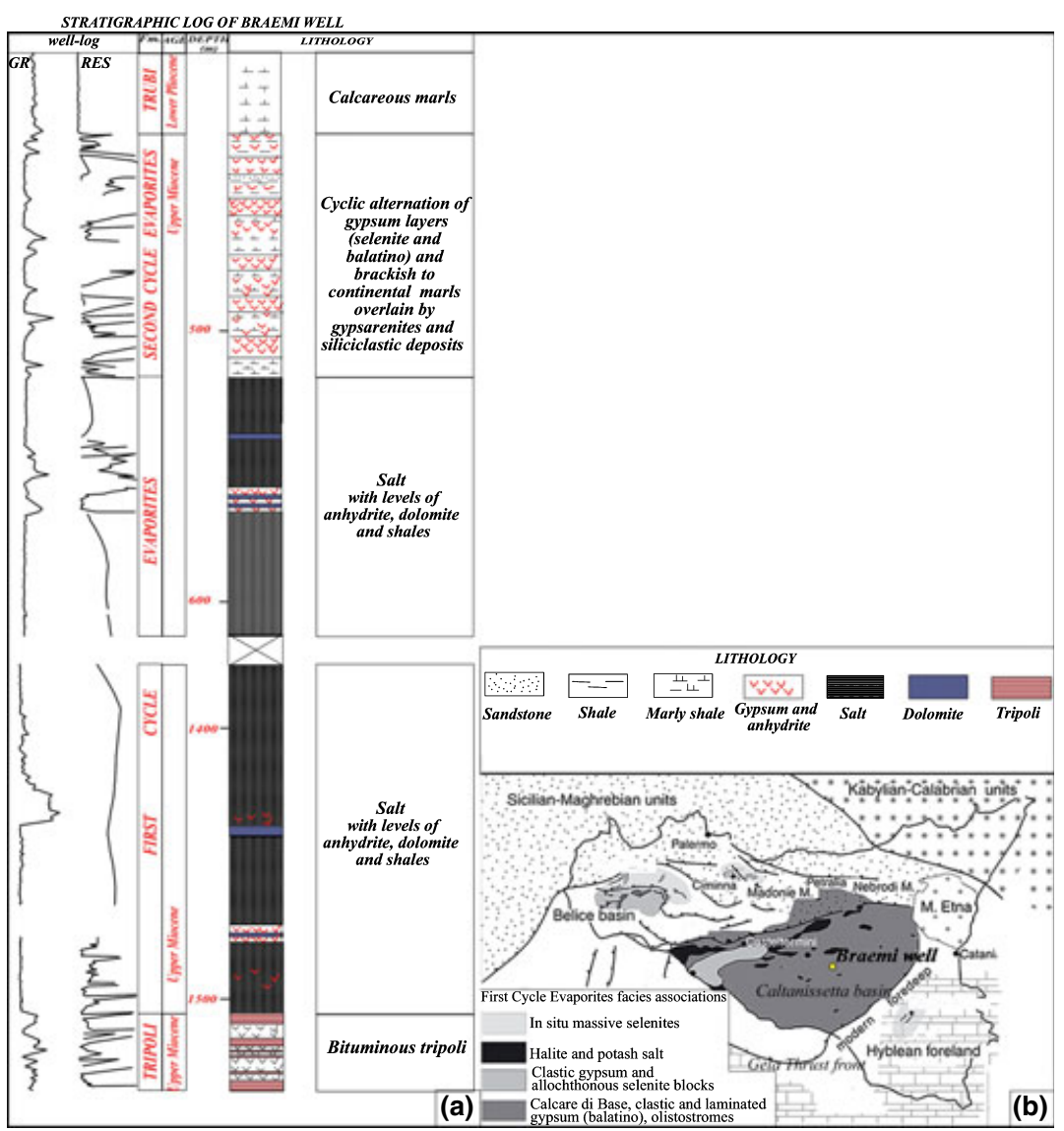

Fig. 3 (a) Simplified log of the Braemi well (T.D. $4050 \mathrm{~m}$ ); note the occurrence of a lower evaporitic subunit, up to $1000 \mathrm{~m}$ thick, made up of salt with local dolomite horizons, sandwiched between pre-evaporitic deposits (i.e. diatomaceous Tripoli Fm.) at the bottom and a cyclic alternation of gypsum layers (selenite and balatino), anhydrite and brackish-to-continental marls with overlying gypsarenites and siliciclastic deposits at the top. (b) Schematic geological map of Sicily showing the distribution of the First Cycle Evaporites (from Roveri et al., 2006) and the location of the commercial well.

is very low (about $1.9 \mathrm{~km} \mathrm{~s}^{-1}$, Makris et al., 1986; De Voogd et al., 1992); I equate this unit to the Plio-Quaternary deposits.

2 A group of reflectors (unit B) consisting of (i) a seismically transparent-to-chaotic interval, $0.2-$ $0.6 \mathrm{~s} / \mathrm{TWT}$ thick, bounded at its base by a strong horizon (transparent subunit) and upward by (ii) a strongly reflecting, well-layered interval, with a thickness ranging between 0.2 and $0.3 \mathrm{~s} / \mathrm{TWT}$ (layered subunit). Unit B is characterized by high P-velocity, from $4.5 \mathrm{~km} \mathrm{~s}^{-1}$ within the layered sub- 


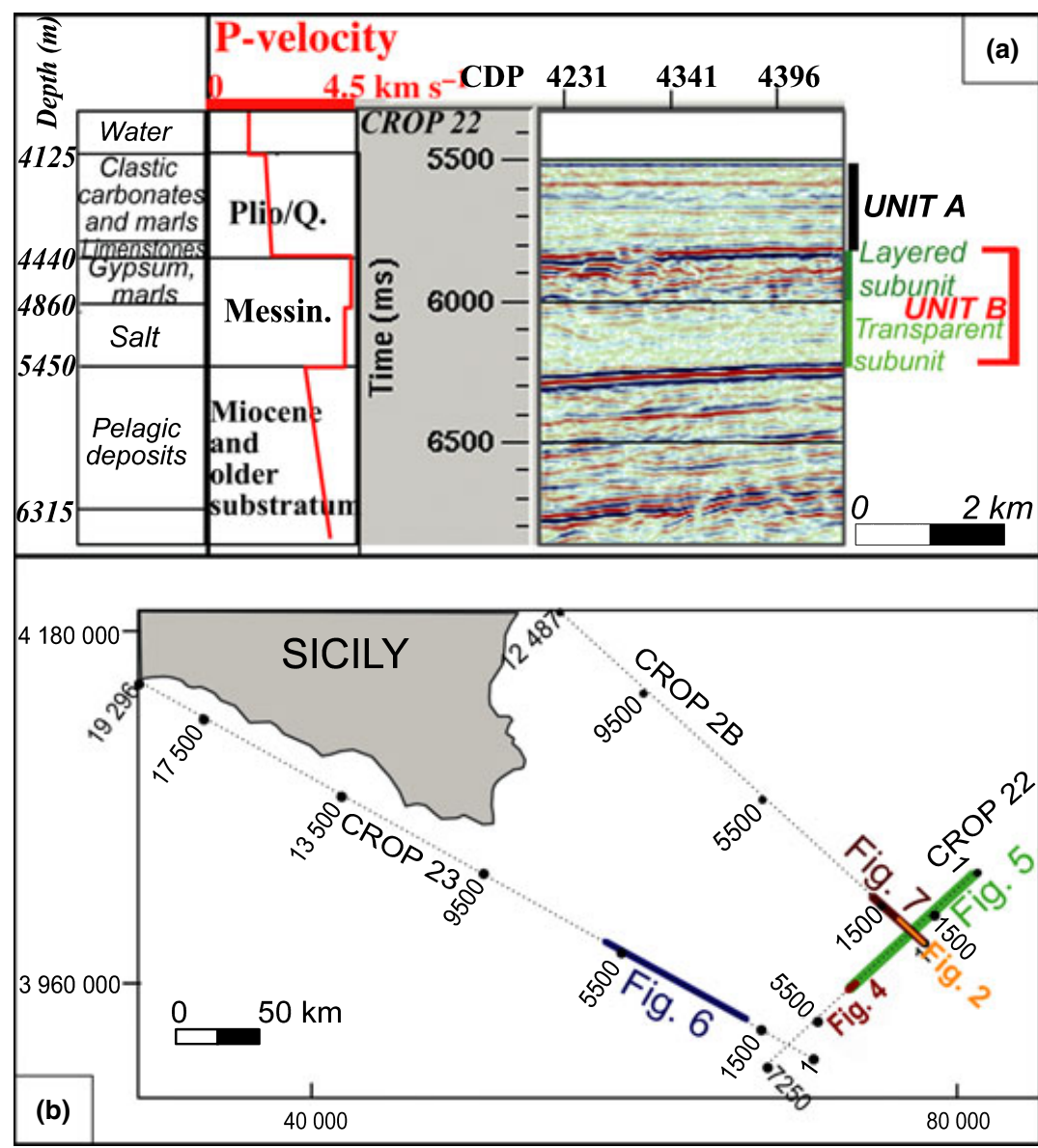

Fig. 4 (a) Seismic facies units recognized on the basis of seismostratigraphic analysis of recently migrated data. Crustal P-velocity-depth functions determined from the ESP 5 (De Voogd et al., 1992) are also shown. (b) Location map of both the transect reported in a (bordeaux red line) and the transects shown in Figs 5-7.

unit to a slightly lower velocity $\left(4.2 \mathrm{~km} \mathrm{~s}^{-1}\right)$ within the transparent subunit, and a velocity inversion at the base (De Voogd et al., 1992). Seismic facies calibrated with refraction data permit the correlation of unit $\mathrm{B}$ with the Mediterranean-wide Messinian evaporites (Hsu et al., 1978); in particular, acoustically transparent facies and $\mathrm{P}$-velocities in the range of about $4.2 \mathrm{~km} \mathrm{~s}^{-1}$, such as those coming from other datasets worldwide (e.g. Le Douaran et al., 1984; Fruehn et al., 2002), suggest a rock salt composition for the lower subunit. Assuming the link between the velocity model and the lithology of previous works (Table 3), I correlate the lower transparent subunit with salt and the overlying layered subunit with gypsum and marls.

\section{Observation and results}

The CROP 22, 23 and 2B seismic profiles discussed here are shown in Figs 5-7 respectively. The PlioQuaternary cover (unit A) is approximately $0.3-0.4 \mathrm{~s} / \mathrm{TWT}$ thick (300-400 m). It appears not deformed, with faint sub-parallel reflectors, in the SW portion of the CROP 22 (4400-3800 CDPs) profile and the SE sectors of the NW-trending CROP 23 (2650-1900 CDPs) and 2B (300-1 CDPs) profiles. On the latter profile, unit A locally shows (CDP 786-361) gentle, short-wavelength undulations suggestive of modest compressional deformation, but no thrust fault is imaged to penetrate this unit clearly.

Along the profiles (3800-11 CDPs, Fig. 5; 5800-2651 CDPs, Fig. 6; 1756787 CDPs, Fig. 7), horizons are imaged to be locally disrupted by thrust faults that sometimes both crop out at the seafloor and offset the underlying unit. Locally, minor thrust faults and folds are also common.

The underlying Messinian unit B shows a maximum thickness of $0.6 \mathrm{~s} / \mathrm{TWT}$ (about $1300 \mathrm{~m}$ ) on the CROP 23 profile and $1.2 \mathrm{~s} / \mathrm{TWT}$ (about $2500 \mathrm{~m}$ ) on the CROP 2B profile, according to the refraction data (De Voogd et al., 1992). On the latter profile, this unit, with a transparent-to-chaotic facies, is bounded at depth by a sub-horizontal, continuous, strong reflector, located at about 6.3-6.4 s/TWT. I interpret this reflector as the basal décollément. In the 786-180 CDPs interval, the top of the Messinian deposits is folded, with a fold wavelength of about $1-1.5 \mathrm{~km}$ and a fold amplitude of about $100 \mathrm{~ms}$.

Transparent and layered subunits are well recognizable on the CROP 23 profile (Fig. 6). Here, slight internal wave-like undulations can be detected in the transparent subunit (1900-2300 CDPs). This subunit is laterally discontinuous NW-ward, locally forming prominent cusps below the several overlying imbricates (Fig. 8) of the layered subunit. I interpret these features as salt-cored thrusts (Jackson, 1995), caused by plastic flows of salt beds at the base of the subunit.

The overlying layered subunit, with a maximum thickness of about $0.2-0.3$ s/TWT (about 450-670 m), appears generally offset by both SE- (Fig. 9) and NW-dipping thrusts, which sole out at its base. Locally double-verging thrust faults offset the overall Messinian sequence.

On the CROP 22 profile (Fig. 5), evaporite seismic facies reflectors are well recognized from 5.8 to $6.2-$ $6.7 \mathrm{~s} /$ TWT. Transparent and layered subunits occur locally, replaced elsewhere by a more chaotic facies. NE-ward, the overall Messinian unit is thickened, presumably due to imbricated thrust faults, and images two superposed imbricated thrust systems; the upper one, with a chaotic facies, is thinner (up to $0.65 \mathrm{~s} / \mathrm{TWT}$, about $1400 \mathrm{~m}$ ) than the lower one and appears markedly detached from it (Fig. 10). Because of both the laterally discontinuous occurrence, well imaged only at the central-north-easternmost 


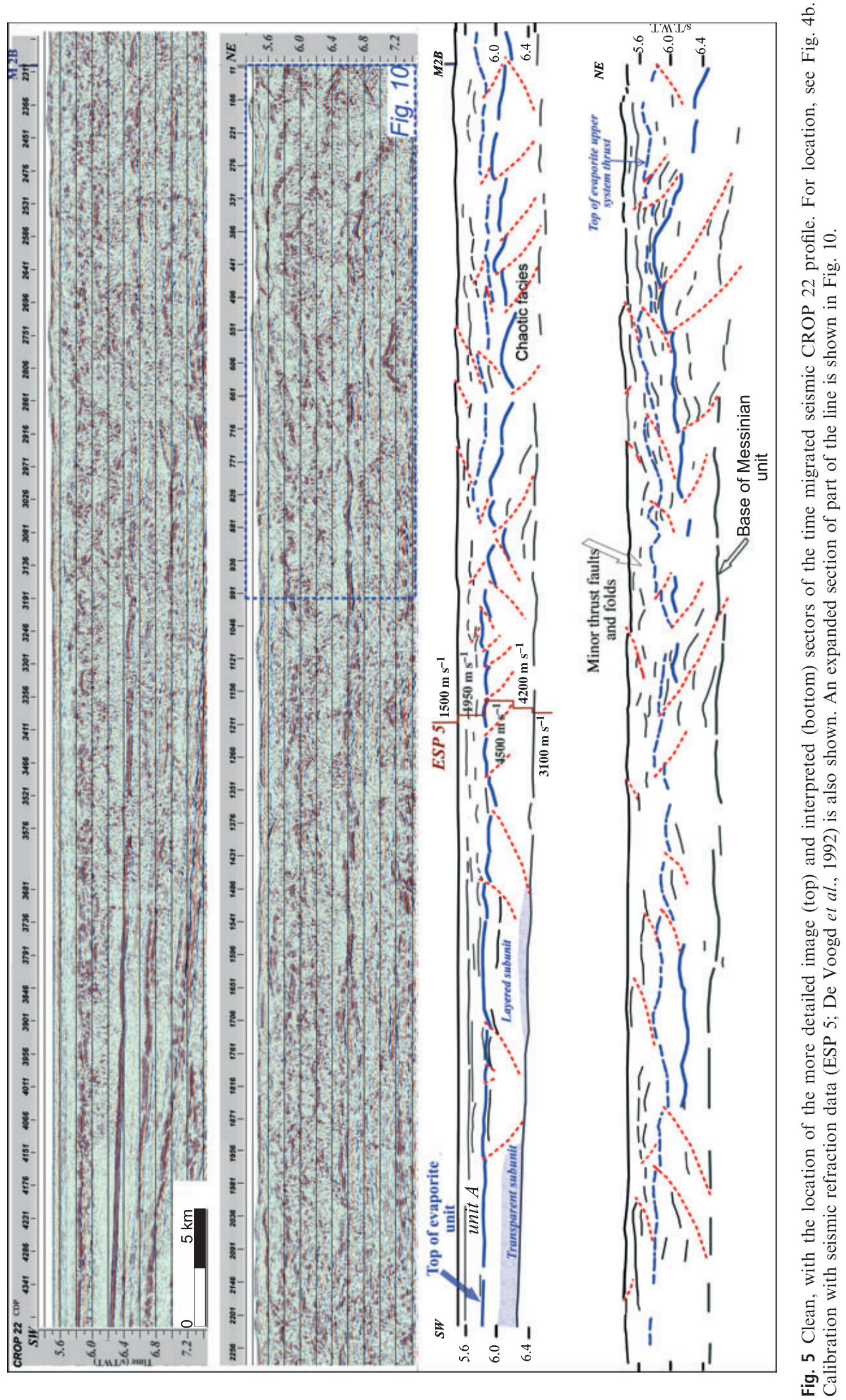




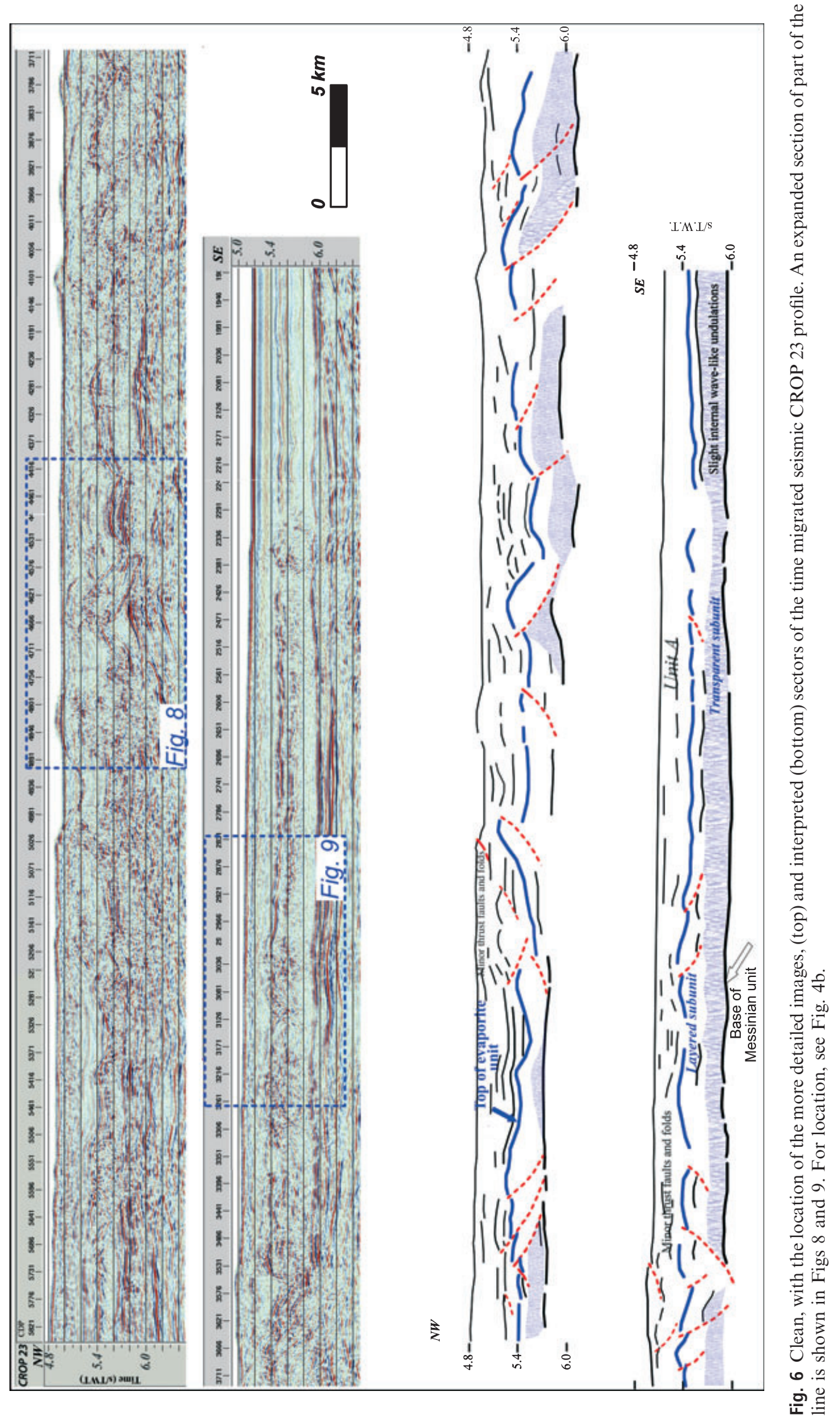




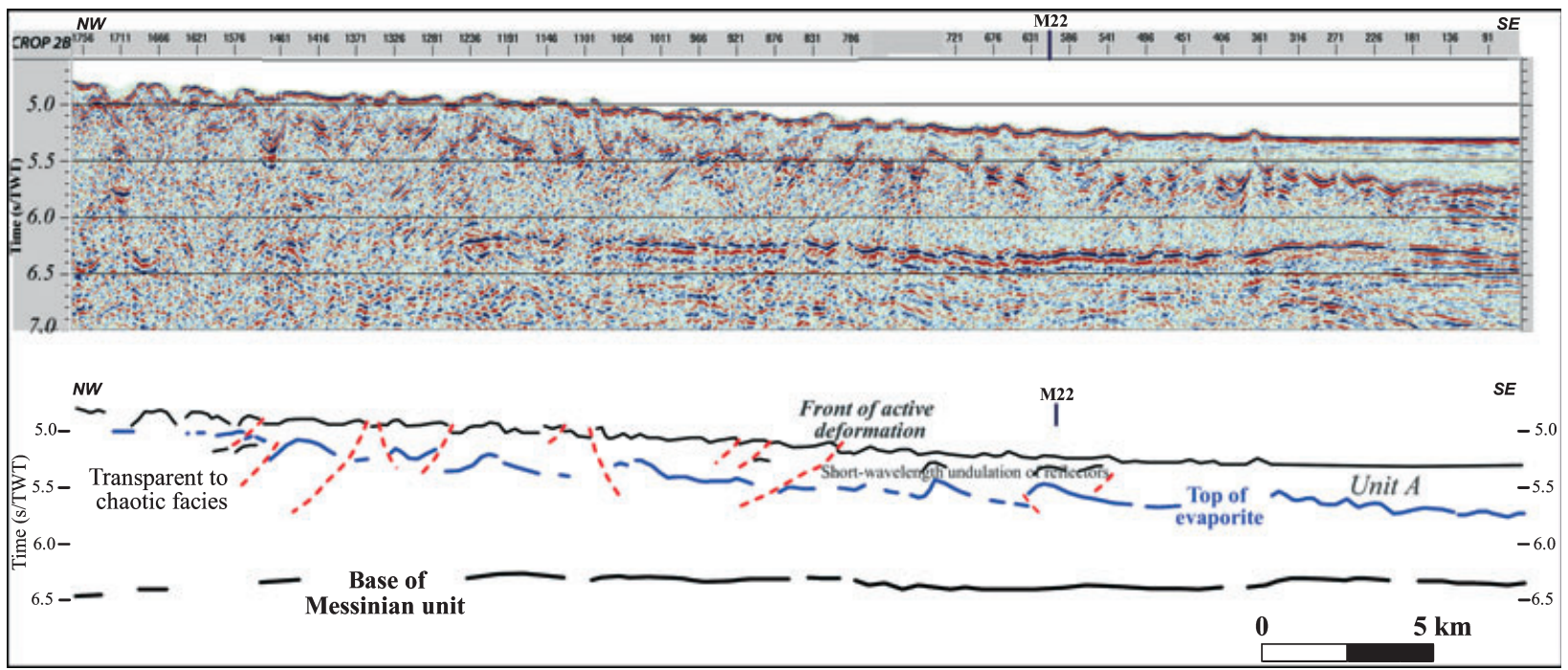

Fig. 7 Clean (top) and interpreted (bottom) sectors of the time migrated seismic CROP 2B profile. See text for discussion. For location, see Fig. 4b.

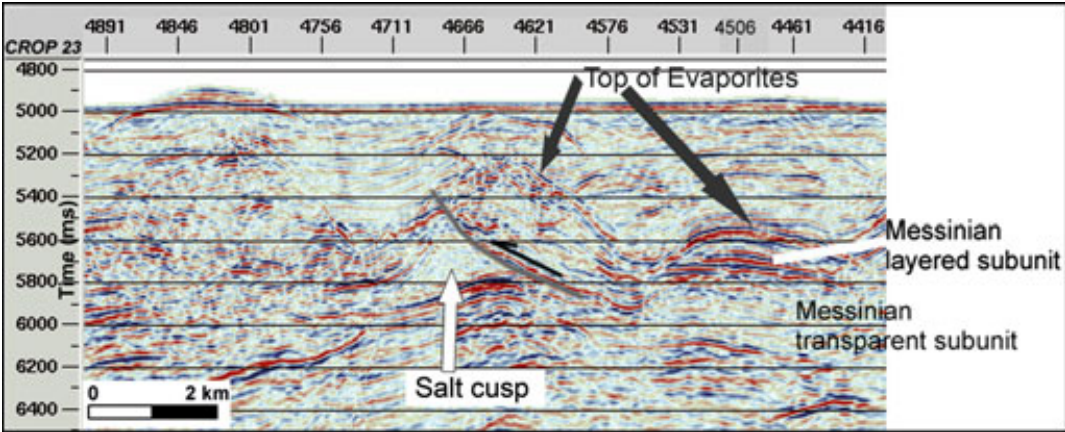

Fig. 8 Seismic close-up from the time migrated CROP 23 profile (Fig. 6) showing salt-cored thrusting structures.

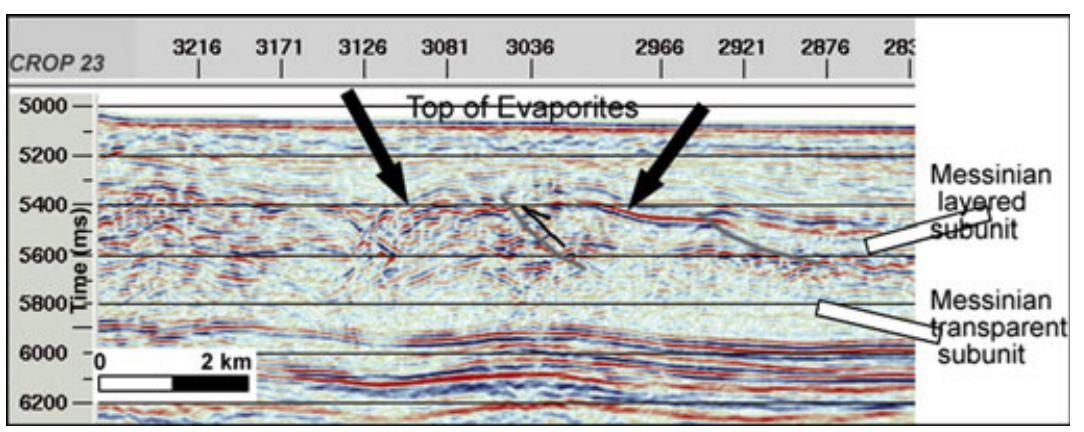

Fig. 9 Seismic close-up from the time migrated CROP 23 profile (Fig. 6) displaying exemplary reverse faulting in the upper Messinian reflectors. No faults occur inside the Messinian transparent subunit (salt). Deformation in the layered subunit is brittle, whereas the salt reacts with ductility.

sector of the CROP 22 profile, and the reduced thickness of the Messinian upper thrust system, I interpret the upper body to be the result of large gravitational glide tectonics over the Messinian salt.

\section{Discussion}

Active accretion at the outermost front is indicated by a distinctive seafloor morphology. The seismostratigraphic analysis of the seismic profiles and the velocity structure, as given by ESP data (De Voogd et al., 1992), suggests a general bipartition of the Messinian unit in the outer ECA, where it consists of a transparent subunit at the bottom and a layered subunit at the top.

Wave-like deformation (Fig. 6) and salt-based compressional structures (Fig. 8) characterize the folded but overall unfaulted lower subunit, suggesting ductile deformation, submitted to a diffuse flow. Thrusting and brittle deformation characterize the overlying subunit, which contains faults soling out at its base.

Both the difference in seismic facies and the difference in deformational style allow a better definition of the unit's stratigraphic layering, which consists of the reflection-free and plastic Messinian salt layer below and the alternation of marls and gypsum above.

Locally, the two Messinian subunits are not well imaged, and a chaotic facies occurs (e.g. Figs 5 and 7).

A different deformational style is evidenced by the occurrence of a series of double-verging imbricated thrust sheets of the whole Messinian unit (e.g. Figs 5-6). This different style of 


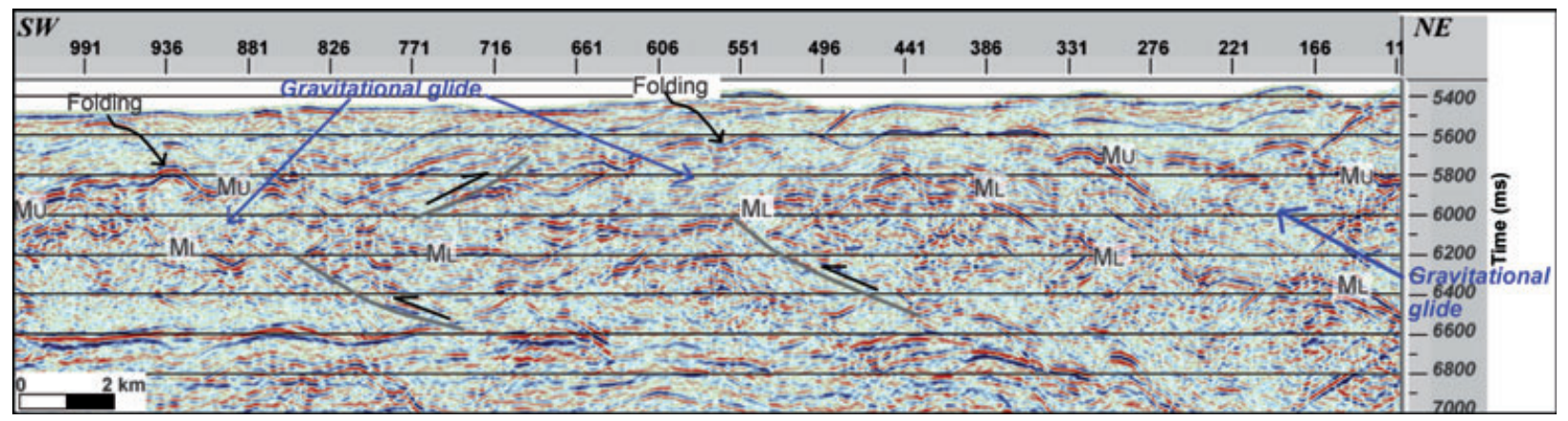

Fig. 10 Seismic close-up from the time migrated CROP 22 profile (Fig. 5) showing two (Mu: the upper one; ML: the lower one) imbricated thrust systems of the Messinian unit.

compressional structures, locally observed, could reflect a different composition (and thus rheology) and/or thickness (ranging between 1300 and $2800 \mathrm{~m}$ ) of the evaporites.

The décollément level of the outermost ECA is located at the base of the evaporites along a relatively flat and gently landward-dipping reflector (Fig. 7). This observation agrees well with the low taper value of the ECA, indicative of very low strength along the décollément level, such as when it is located at the base of the salt (e.g. Reston et al., 2002). This observation is also confirmed by the local occurrence of double-verging thrust sheets offsetting the whole Messinian unit, indicative of a 'weak' décollément level, as also highlighted by analogue sandbox models (e.g. Liu et al., 1992) as an effect of low basal friction.

At the south-easternmost border of the study area (Fig. 1), chaotic deposits with both reduced thickness and narrow areal widening have been seismically imaged (Fig. 5) as the product of gravity-gliding tectonics. These gravity transported bodies form imbricate allochthonous units overlying the imbricate thrust-sheets of the Messinian evaporite deposits. Locally, gravity tectonics also involve part of the overlying Plio-Quaternary deposits, based on the occurrence of minor thrust faults and folds (Figs 5 and 6).

This large-scale instability of the area, since the Late Messinian, could be due to a progressive increase in the wedge slope steepness, consequent to the thickening of a sub-critically tapered wedge. However, it could be hypothesized that the salt tectonics have also played a role in the emplacement of the chaotic succession. In this case, the gravity-gliding tectonics might well reduce the top of the taper, contributing to lowering the taper value detected for the ECA.

\section{Concluding remarks}

Post-stack time migration of the Ionian CROP seismic data provides new constraints on the structures and processes characterizing the outermost ECA.

1 A more detailed stratigraphic framework than previously known of the Messinian evaporite deposits, consisting generally of gypsum and marls overlying salt, is given. The 'upper' evaporite layer shows evidence of brittle deformation, while the 'lower' evaporite layer acted as a widespread ductile layer, through the development of salt-cored thrusting structures.

2 A lateral variation in composition (and hence in stratigraphy) and/or thickness of the Messinian deposits is reflected by a change in the style of the compressional structures, with the development of double-verging thrust faults offsetting the whole Messinian sequence.

3 Gravitational glide tectonics have characterized the outermost ECA since the Late Messinian, due to the occurrence of both salt and a wedge slope too steep to support a skinny evaporite-based top layer (a nearsurface 'olistostrome').

\section{Acknowledgements}

This research was supported by 'PRIN' 2008 and 'SIRIPRO' Project grants (resp. Professor R. Catalano). The author wishes to thank Professor Albert Bally for his extremely stimulating and constructive suggestions. Beatrice Magnani is warmly acknowledged for her helpful support in reprocessing of seismic profiles at the CERI (Center for Earthquake Research and Information of the University of Memphis, TN, USA). Two referees, Professor M.R Barchi and R.W.H. Butler, and the Scientific and Associate editors are acknowledged for their thoughtful and constructive reviews, which improved the manuscript. Special thanks to Professor R. Catalano for his critical comments and discussions.

\section{References}

Berkhout, A.J., 1980. Seismic MigrationImaging of Acoustic Energy by Wavefield Extrapolation. Elsevier, Amsterdam, 339 pp.

Butler, R.W.H., Lickorish, W.H., Grasso, M., Pedley, H.M. and Ramberti, L., 1995. Tectonics and sequence stratigraphy in Messinian basins, Sicily: contraints on the initiation and termination of the Mediterranean salinity crisis. Geol. Soc. Am. Bull., 107, 425-439.

Camerlenghi, A., 1991. Il Diapirismo d'Argilla sulla Dorsale Mediterranea. Tesi di Dottorato, Dipartimento di Scienze della Terra, Università degli Studi di Milano, Milano, 173 pp.

Catalano, R. and Sulli, A., 2006. Crustal image of the Ionian basin and accretionary wedge. Boll. Geofis. Teor. Appl., 47, 343-374.

Catalano, R., Doglioni, C. and Merlini, S., 2001. On the Mesozoic Ionian basin. Geophys. J. Int., 143, 1-24.

Catalano, R., Doglioni, C., Merlini, S. and Sulli, A., 2002. The subduction of the Ionian crust and the Outer Calabrian accretionary wedge. EAGE Workshop, May 27-30, Florence, Italy.

Cernobori, L., Hirn, A., McBride, J.H., Nicolich, R., Petronio, L., Romanelli, $M$. and STREAMERS/PROFILES WG, 1996. Crustal image of the Ionian 
basin and its Calabrian margins. Tectonophysics, 264, 175-189.

Chamot-Rooke, N., Rangin, C., Le Pichon, X. and Dotmed Working Group, 2005. DOTMED: a synthesis of deep marine data in eastern Mediterranean. Mèm. Soc. Gèol. France, 177, 1-64.

Chiarabba, C., De Gori, P. and Speranza, F., 2008. The southern Tyrrhenian subduction zone: deep geometry, magmatism and Plio-Pleistocene evolution. Earth Planet. Sci. Lett., 268, 408-423.

Clift, P.D. and Vannucchi, P., 2004. Controls on tectonic accretion versus erosion in subduction zones: implications for the origin and recycling of the continental crust. Rev. Geophys., 42, RG2001. DOI: 10.1029/2003RG000127.

Dahlen, F.A., Supple, J. and Davis, D., 1984. Mechanics of fold-and-thrust belts and accretionary wedges: cohesive Coulomb theory. J. Geophys. Res., 89, 10087-10101.

Davis, D., Suppe, J. and Dahlen, F.A., 1983. Mechanics of fold-and-thrust belts and accretionary wedges. J. Geophys. Res., 88, 1153-1172.

De Astis, G., Ventura, G. and Vilardo, G., 2003. Geodynamic significance of the Aeolian volcanism (Southern Tyrrhenian Sea, Italy) in light of structural, seismological, and geochemical data. Tectonics, 22, TC1040. DOI: 10.1029/2003TC001506.

De Voogd, B., Truffert, C., ChamotRooke, N., Huchon, P., Lallemant, S. and Le Pichon, X., 1992. Two-ship deep seismic soundings in the basins of the Eastern Mediterranean Sea (Pasiphae cruise). Geophys. J. Int., 109, 536-552.

Decima, A. and Wezel, F.C., 1971. Osservazioni sulle evaporiti Messiniane della Sicilia centro-meridionale. Riv. Min. Sicil., 130-134, 172-187.

Finetti, I., 1982. Structure, stratigraphy and evolution of central Mediterranean. Boll. Geofis. Teor. Appl., 24, 247-315.

Finetti, I., 2005. CROP Project: deep seismic exploration of the Central Mediterranean and Italy. In: Atlases in Geoscience 1 (I.R. Finetti, ed.), pp. 1-779. Elsevier, Amsterdam.

Fruehn, J., Reston, T., von Huene, R. and Bialas, J., 2002. Structure of the Mediterranean Ridge accretionary complex from seismic velocity information. Mar. Geol., 186, 43-58.

Hersey, J.B., 1965. Sedimentary basins of the Mediterranean Sea. In: Submarine
Geology and Geophysics (W.F. Whitard and W. Bradshaw, eds), pp. 75-91. Proceedings of the 17th Symposium of the Colston Research Society, London.

Hsü, K.J., Montadert, L., Bernoulli, D., Bizon, G., Cita, M., Erickson, A., Fabricius, F., Garrison, R.E., Kidd, R.B., Méliéres, F., Müller, C., and Wright, R.C., 1978. Initial Report of the Deep Sea Drilling Project, 42 Part 1. U.S. Government Printing Office, Washington, pp. 1-1249.

Jackson, M.P.A., 1995. Retrospective salt tectonics. In: Salt Tectonics: A Global Perspective, Vol. 65 (M.P.A. Jackson, D. Roberts and S. Snelson, eds), pp. 1-28. AAPG, Tulsa, TX.

Le Douaran, S., Burrus, J. and Avedik, F., 1984. Deep structure of the northwestern Mediterranean Basin: results of a two-ship seismic survey. Mar. Geol., 55, 325-345.

Lenci, F. and Doglioni, C., 2007. On some geometric prism asymmetries. In: Thrust Belts and Foreland Basins: From Fold Kinematics to Hydrocarbon Systems (O. Lacombe, J. Lavè, F. Roure and J. Verges, eds), pp. 41-60. Frontiers in Earth Sciences, Springer, Berlin.

Liu, H., McClay, K.R. and Powell, D., 1992. Physical models of thrust wedges. In: Thrust Tectonics (K.R. McClay, ed.), Chapman and Hall, London, pp. 71-81.

Makris, J., Nicolich, R. and Weigel, W., 1986. A seismic study in the western Ionian Sea. Ann. Geophys. B, 4, 665-678.

Merlini, S., Cantarella, G. and Doglioni, C., 2000. On the seismic profile CROP M 5 in the Ionian Sea. Boll. Soc. Geol. It., 119, 227-236.

Montadert, L., Letouzey, J. and Mau!ret, A., 1978. Messinian event: seismic evidence. In: Initial Reports of the DSDP, Vol. 42, Part 1 (K. R. Hsu and L. Montadert, eds), pp. 1037-1050. US Government Printing Office, Washington, DC.

Polonia, A., Torelli, L., Capozzi, R., Riminucci, F., Artori, A., Ramella, R. and Calarc Group, 2008. African/ Eurasian plate boundary in the Ionian Sea: shortening and strike slip deformation in the outer Calabrian Arc accretionary wedge. GNGTS 2008, Extended Abstract Book, 37-40.

Reston, T.J., von Huene, R., Dickmann, T., Klaeschen, D. and Kopp, H., 2002.
Frontal accretion along the western Mediterranean Ridge: the effect of Messinian evaporites on wedge mechanics and structural style. Mar. Geol., 186, 59-82.

Rossi, S. and Sartori, R., 1981. A seismic reflection study of the External Calabrian Arc in the northern Ionian Sea (eastern Mediterranean). Mar. Geophys. Res., 4, 403-426.

Roveri, M., Manzi, V., Lugli, S., Schreiber, B.C., Caruso, A., Rouchy, J.M., Iaccarino, S.M., Gennari, R. and Vitale, F.P., 2006. Clastic vs. primary precipitated evaporites in the Messinian Sicilian basins. R.C.M.N.S. International Congress Parma 2006 "The Messinian salinity crisis revisited II" post-congress Fieldtrip. Acta Natur. Aten.-Parm., 42, 125-199.

Sartori, R., 1982. L'arco calabro-peloritano. Aspetti di geologia marina. Rend. Soc. Ital. Mineral. Petrogr., 38, 941-950.

Stampfli, G.M., Mosar, J., Favre, P., Pillevuit, A. and Vannay, J.C., 2001. Permo-Mesozoic evolution of the western Tethyan realm: the Neotethys/ East-Mediterranean basin connection. In: Peritethyan Rift/Wrench Basins and Passive Margins (IGCP 369) (W. Cavazza, A.H.F.R. Robertson and P.A. Ziegler, eds), pp. 51-108. PeriTethys Memoir 6, Mémoires du Museum National d'Histoire Naturelle, Paris.

Tay, P.L., Jones, K., Lonergan, L., Warner, M. and IMERSE Working Group, 2002. Deep evaporite basins on the inner unit of the Mediterranean accretionary complex. Mar. Geol., 186, 167-194.

Torelli, L., Mussoni, P., Polonia, A., Ligi, M., Zitellini, N., Capozzi, R. and The Calarc Group, 2007. Structure and evolution of the Calabrian Arc accretionary wedge (Ionian Sea) from deep reflection seismic data, Geoitalia 2007, Epitome, 2, 138.

Wortel, M.J.R. and Spakman, W., 2000. Subduction and slab detachment in the Mediterranean-Carpathian region. Science, 290, 1910-1917.

Received 1 October 2009; revised version accepted 22 July 2010 